\title{
Evolutionary Method for Learning to Read
}

\section{Método evolutivo para aprender a leer}

\author{
FOKIN, Sergei Konstantinovich $\dagger^{*} \&$ ARICEAGA-PAREDES, Rafael \\ Escuela Normal No. 3 de Toluca, México \\ Centro clínico de oído, nariz y garganta \\ ID $1^{\text {st }}$ Author: Sergei Konstantinovich-Fokin / ORC ID: 0000-0001-8975-9678 \\ ID $1^{\text {st }}$ Coauthor: Rafael Ariceaga-Paredes / ORC ID: 0000-0003-1079-5380
}

DOI: $10.35429 / J B E .2021 .14 .5 .1 .9$

Received July 10, 2021; Accepted December 30, 2021

\begin{abstract}
In the long history of education, the priority of teaching and learning had genetically as a human need and eagerness to know how to read. The thirst to know the world around us, saying metaphorically, can be extinguished while man can read the Book of Life. To develop reading skills, the interest in reading and promote universal culture, methods are developed that facilitate the obtaining of reading knowledge. Through the research "Formation of knowledge for reading through musical procedures" (2002-2008) a technological medium was created organized by the two modules: "Intelligent system in sensory and cognitive development for the prereading stage" and the method, including software, so that the young child can learn to read in a short time, acquiring, building, and forming the necessary knowledge. The technological support made it possible to establish the tuned communication in the school classroom between teacher and student and, at the same time, to objectify the process of teaching and learning didactics to reading.
\end{abstract}

Method, Learning, Reading

\section{Resumen}

En larga historia de la educación la prioridad de enseñanza y aprendizaje tenía genéticamente como una necesidad humana y avidez de felicitad saber a leer. La sed conocer el mundo que nos rodea, diciendo metafóricamente, puede apagarse mientras que el hombre puede leer el Libro de la Vida. Para desarrollar la habilidad lectora, el interés de leer y fomentar la cultura universal se elaboren los métodos que facilitan la obtención de los conocimientos de lectura. A través de la investigación "Formación de los conocimientos para la lectura mediante de los procedimientos musicales" (2002-2008) fue creado un medio tecnológico organizado por los dos módulos: "Sistema inteligente en el desarrollo sensorial y cognitivo para la etapa prelectura" y el método, incluyendo software, para que el niño de edad temprana puede aprender a leer en corto tiempo, adquiriendo, construyendo y formando los conocimientos necesarios. El apoyo tecnológico posibilitó establecer la comunicación sintonizada en el aula escolar entre docente y alumno y, en el mismo tiempo, objetivar el proceso de la didáctica de enseñanza y aprendizaje a la lectura.

Método, Aprendizaje, Lectura

Citation: FOKIN, Sergei Konstantinovich \& ARICEAGA-PAREDES, Rafael. Evolutionary Method for Learning to ReadJournal Civil Engineering. 2021. 5-14: 1-9

\footnotetext{
* Correspondence to Author (e-mail: fokin.sergei.19@ normal3toluca.edu.mx)

$\dagger$ Researcher contributing as first author.
} 
Legere enim et non intelligere negligere est Macus Porcius Cato el Viejo

\section{Introduction}

To leave without attention to know the world around us, is to ignore reality. That is, the Book of Life man can neither read nor know. Knowledge is a social, historical, and cultural production that is presented as a brain of the Universe through which man manages to transform it. Among the main knowledge that the human being has developed to communicate, is the language, which allows him to communicate with his peers, allows him to capture and understand ideas of speech and listening. In the research "Formation of knowledge for reading through musical procedures" (2002-2008), carried out at the Normal School No.3 of Toluca, the main methods for teaching reading and writing that have been applied in Mexico were analyzed, from the catechist booklet of the syllabary of San Miguel de Fray Pedro de Gant to the global and eclectic methods, in total there were 36 methods (Campuzano Reyna, 2005).

Organized in five methodological typologies, the following structure was presented in the area of linguistics: spelling or alphabetical, based on the pronunciation of the name of the letter; the phonetics that initiate the pronunciation of each letter with the sound that corresponds to them; syllabic methods as the primary element of the word; the global ones that prioritize prayer as an expression of thought; as well as combined and eclectic methods, which combine various teaching procedures.

In the one concerning the march, the methods are located as synthetic-analytical, they begin with the letter to elaborate then syllables, words, phrases, and sentences; analytical-synthetic start the word, others from the phrase and sentences, to arrive some to the syllables, letters or sounds. Simultaneity refers to the learning of reading, affirming it when writing; methods that first teach reading and then writing are mastered successively; those who present both handwritten and printed characters are identified as mixed.
Prof.C. Rébsamen, introducer in Mexico of the typology of phonetics based on normal words, expressed "It seems logical that every method of reading and whatever it is march and its procedures, try to familiarize children sometime with sounds of letters, to learn to read." In this way a method for reading "Learning to read" was developed. The proposal was as follows: child in the short term has to learn to read. The condition of the implementation of the method was to put between educator and the student a digital medium, computer.

The word, which appears as a material object, pronounced, and heard, through sensation and perception, was transferred to the mind of the listener, transforming the ideal object into the form of the audiovisual image. At this moment the act of speech is performed, that is, speech. (Trubetzkoy, 1939).

The word itself is a knowledge, which is transmitted to the child, for the first time by the people around him and, later, by the educator. The word expressed by the teacher, in other words, the sounded thought and materialized by the environment on paper of the physical sound, takes over the hearing of the child, influences the mind and makes think.

The reciprocal relationship between a world of the physical state and the world of the psychic state (Popper K. 1994), named by Descartes as the relationship between consciousness and body, in the definition should be real. The reality of these particularly remarkable events is presented in the educational process, in the birth of a thought in the student. The desire to bring his own thought to the other, the student expresses it through speech. Speech is a mental product of the student. According to Popper (Popper, 1994), it's the third world.

To think that the child's appropriation of speech might be enough for a learning of reading is to fall into a mistake. Reading is a set of practices and procedures in working with text, directed towards the extraction of information and perception, and understanding. The teaching role in this process is to teach reading and teaching reading. The student's role is in learning to read through the process of learning to read. This process can be determined positive or negative. 
Process with the achievement of the objectives, the one among them is that the student learns to read, it can be done only when there is an understanding through the tuning between the speaker (teacher) and the listener (student).

\section{Problem}

It is well known that the teaching of reading and reading and learning to read and read are processes linked to the communication process in the school classroom, where the act of speaking and listening is carried out. It is taken into consideration to say, that between teacher and student a communication process is executed, the object of which is reading. At this time, it is evidently considered that the main role in the teaching process plays the teaching experience (Jacobson R. 1975). We know that the experience should include knowledge of phonetics and phonology, speech, and its perception, listening and minimum sound units of language, articulation and acoustics, the phonetic structure of the syllable and word, intonation and modulation of the voice, the tuning of the auditory systems of the subjects in the school classroom among others.

It should be noted that teacher verbally transmits the word, student, perceiving, must discriminate the tones of that word, because the appropriation of speech can be nothing more than listening to the speech of adults (Luria A. R., 1984). If it had been possible to say that the verbal message is the experience that is transmitted and received with communication, even though that statement is partially correct, it would undoubtedly alter reality.

Derived from the results of the research and considering that circumstance, that the knowledge for reading as a basis includes the sounds of speech, those with extreme need should be differentiated; with what I had said, we must continue to recognize, that for teachers phonetic-phonological orientation is necessary. The proposal includes the development of the auditory system of teacher and student. They can replicate that the capacities developed in teacher and student are not fundamental, because the subjectivity of the subjects in the educational process can contract acousticpsychological side effects, such as:
Discrepancy of the acoustic process of speech and the perception of speech, mechanism of speech production and the discernment of the image of speech (Found, 2012). For if it were impossible, without compromising the truth, to deny to some extent these opinions. The goal was to create and implement a method so that the student can learn to read.

\section{Theoretical references}

Evolutionary method is an instrument that strengthens and enriches the formation of knowledge for reading in the process of teaching and learning developing, sensory and cognitively to the subjects of pedagogical communication. Method to learn to read and Intelligent system in sensory and cognitive development for the pre-reading stage were the last part of the research. The structure of theoretical references was organized as follows:

1. Models for creating the method

2. Speech sounds and their perception

3. Factors to complement the theories

- Cochlear mechanics

- Demonstration of three degrees of modulation

- Syllabic organization of the word

\subsection{Models for creating the method}

EIn the creation of a method to learn to read, two traditional models were used, such as: function and activity. The essence of the functional model is in the reciprocal action between physiological and psychological processes (hearing) and phenomena (speech sounds) (Anojin, 1998), (Vygotsky, 1995) and (Luria A. R., 1974). Of physiology it is known that the external event, the word pronounced by the teacher as a stimulus, is innervated the sensory organ, ear of the student, then passes to the central nervous system, transforming, and becomes the sensation and impression (Schmidt R.F. 1980).

They, relating to the memory (the experience) of the student, reproduce the sound image of the word expressed by the teacher, but before the act of behavior is carried out the image coincides with the memory and motivation to obtain in the mind some variants of the actions. 
In the mind appears a model called the acceptor of the result of the action. From the very beginning of the action (efferent excitation), information about it is transmitted to the central nervous system and compared to the acceptor of the action. After a while, the information about the parameters of the result of the action already performed (inverse afferent) also gets there. If the parameters of the action performed do not correspond to the acceptor of the action (the set goal), then a negative emotional state occurs. If this coincidence occurred on the first attempt to perform the action, then a positive emotion arises.

With a function model, the model of the activity is directly joined, the essence of which is in the actions of the teacher and student. Teacher and student are active subjects in the communication process. Teacher develops linguistic activity, program and analyzes the results of student work in the process of communication.

\subsection{Speech sounds and their perception}

La base de las relaciones comunicativas de los sujetos del aula escolar es lenguaje. Lenguaje es un medio de las relaciones interpersonales y de la transmisión del pensamiento desde un individuo hasta el otro (Saussure, 1968-1974) y (Courtenay, 1963). La ciencia del lenguaje está dividida en dos partes: fonética, que es ciencia sobre los sonidos del acta de habla, y fonología, que es la ciencia sobre los sonidos del lenguaje (Trubetzkoy, 1939).

El habla es una acción con el uso de los sonidos que se efectúa por hombre para la transmisión de pensamiento, sentido $\mathrm{y}$ sentimiento. La más pequeña unidad del habla es fonema (Zinder, 2007). Imposibilidad de la división de los términos de una oración fue demostrada por Flanagan (Flanagan, 1968). Calidad de combinable de los fonemas se permitió definir una ley universal: la unión de $\mathrm{CV}$ es lo admisible universalmente para todas las lenguas del mundo (Trubetzkoy, 1939). Partiendo de lo dicho, se propone en el método en el periodo de pre-lectura las siguientes combinaciones de los fonemas: $\mathrm{CV}, \mathrm{V}$ y $\mathrm{C}$. The basis of the communicative relationships of the subjects of the school classroom is language.
Language is a means of interpersonal relationships and the transmission of thought from one individual to the other (Saussure, 1968-1974), (Courtenay, 1963). The science of language is divided into two parts: phonetics, which is science about the sounds of the speech act, and phonology, which is the science about the sounds of language (Trubetzkoy, 1939). Speech is an action with the use of sounds that is performed by man for the transmission of thought, meaning and feeling. The smallest unit of speech is phoneme (Zinder, 2007). Impossibility of dividing the terms of a sentence was demonstrated by Flanagan (Flanagan, 1968). Combinable quality of phonemes allowed to define a universal law: the union of $\mathrm{CV}$ is universally admissible for all the languages of the world (Trubetzkoy, 1939). Based on what has been said, the following combinations of the phonemes are proposed in the method in the pre-reading period: $\mathrm{CV}, \mathrm{V}$ and $\mathrm{C}$.

\subsection{Factors to complement the theories}

Factores para complementar las teorías bajo el principio de la economía en los cambios fonéticos (Martinet, 1955). El principio se entiende semánticamente. Es decir, que el significado de este principio, entretanto con el otro que se llama el principio de mínima acción, se usa en todos los procesos, como: fisiológicos, psicológicos y lingüísticos. Factors to complement theories under the principle of economics in phonetic changes (Martinet, 1955). The principle is understood semantically. That is, the meaning of this principle, meanwhile with the other that is called the principle of minimum action, is used in all processes, such as: physiological, psychological, and linguistic.

\section{Factors:}

\section{Cochlear mechanics}

2. Demonstration of modulation in three degrees of kinship of tonalities

3. Syllabic organization of the word

\subsubsection{Cochlear mechanics}

The reason for analyzing the passage of acoustic stimulus from the external medium to the peripheral auditory system was some inaccuracies in the theoretical writings of Herman von Helmholtz and Georg von Békésy. First inaccuracy

FOKIN, Sergei Konstantinovich \& ARICEAGA-PAREDES, Rafael. Evolutionary Method for Learning to ReadJournal Civil Engineering. 2021 
According to Helmholtz (Helmholtz, 1913), when touching the oval window with a glass stick, the cochlear labyrinth fluid flows from the oval window (MO) to the round window (MR). The round membrane has equal movement. This test is called the Politzer test. That is, in the first place, the MR function is passive, and, in the second place, the movement of liquid is the source and cause of the electrical signal produced by the Hair Cells transmitting the signal by cochlear nerve to the central auditory system.

Correct answer to the incorrect one (the test is done when there is de-tightness of the middle ear) is: the condition of the organ to make physiological studies must be untouchable, otherwise, the experiment presents the erroneous results.

\section{Second inaccuracy}

According to Békésy (Békésy, 1960), the resonance phenomena that appear in the basilar membrane (MB) are the effect of the action of "a traveling wave", which in high frequencies reaches the base of the cochlea and in low frequencies runs to apex. Among other things, there are several questions, to which the theory of auditory reception cannot answer. For example, if it is a pure precise tone, how does the traveling wave determine its immovable place in MB? Cohen(Cohen, 1973) describes Georg von Békésy's model: "He built the cochlear model; found the places in the basilar membrane that respond to the frequency of the stimulus. As he changed the frequency, Békésy felt a pressure point move along his arm (my marking)." He soon realized, "that Reissner's membrane (?) and the basilar membrane easily transmit sound, the two channels act as one with respect to sound transmission."

\section{The resolution of the doubt}

Procediendo de la teoría de Georg von Békesy, el estímulo acústico mediante del mecanismo de la recepción constituye la onda viajera, la cual "corre" la distancia desde ventana oval hasta ventana redonda. En tal movimiento físico se deberían ser "tocadas" todas las células ciliadas, internas y externas. Efecto de la onda viajera es que deben reproducirse sucesivamente todos los sonidos tonales $\mathrm{y}$ ruidosos.
Para comprobar los hechos que no hay la coincidencia en mecánica coclear, fue aplicado test en MRI (convenio con ISSMYM, 2004). El resultado de 181 imágenes fue la presencia en $\mathrm{MB}$ un estímulo "N" en lugar exacto de la frecuencia del estímulo (Figure 1 y 2). Los resultados de esta parte de investigación (principios de economía o de la acción mínima), por un lado, fueron presentados en el XXXI World Congress of Audiology desde un punto de física en "Some Consideration about Natural Laws and Principles in Cochlear Mechanics" (Ariceaga Paredes R., 2012), por el otro lado, se conjuntaron a un libro "Discovering the Path to Comprehension of the Cochlea Mechanics" (Fokin S. A., 2018).

Proceeding from the theory of Georg von Békésy, the acoustic stimulus through the mechanism of reception constitutes the traveling wave, which "runs" the distance from oval window to round window. In such physical movement all hair cells, internal and external, should be "touched". The effect of the traveling wave is that all tonal and noisy sounds must be played successively. To verify the facts that there is no coincidence in cochlear mechanics, MRI tests were applied (agreement with ISSMYM, 2004). The result of 181 images was the presence in $\mathrm{MB}$ of an "N" stimulus in exact place of the frequency of the stimulus (Figure 1 and 2). The results of this part of research (principles of economics or minimal action), on the one hand, were presented at the XXXI World Congress of Audiology from a physics point in "Some Consideration about Natural Laws and Principles in Cochlear Mechanics" (Ariceaga Paredes R., 2012), on the other hand, they were combined with a book "Discovering the Path to Comprehension of the Cochlea Mechanics" (Fokin S. A., 2018).

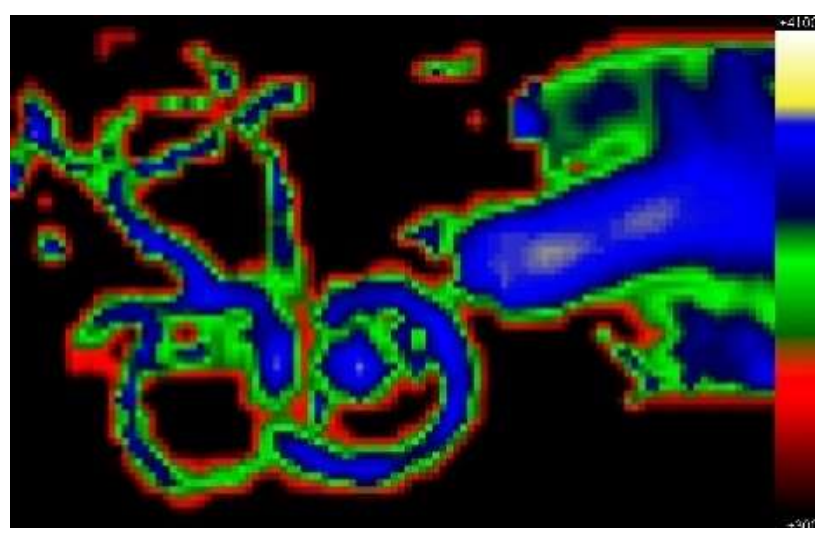

Figure 1 


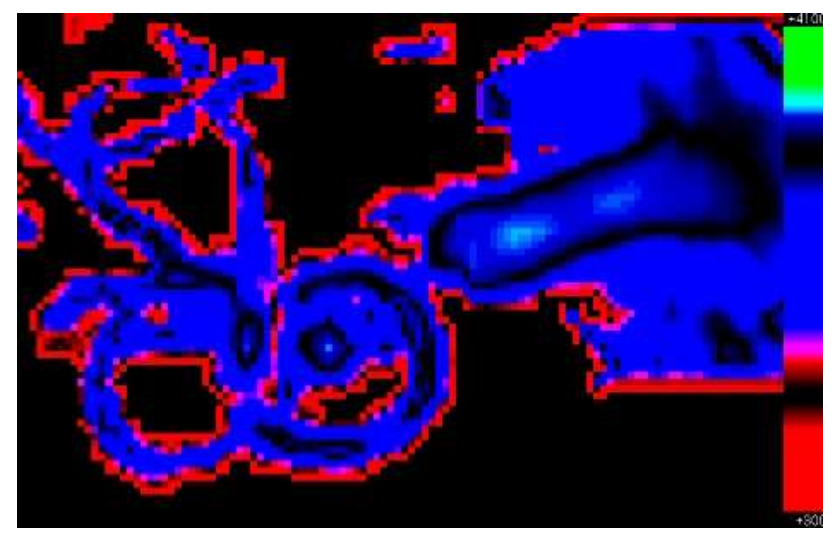

Figure 2

a) Demostración de la modulación en tres grados del parentesco de las tonalidades

Fue desarrollado el libro "Tratado de harmonía" (Fokin S. K., 2017) con una visión de la anotomía de la cóclea, donde hipotéticamente se asocia los lugares de las Cilios Ciliadas Internas que se presentan en la anatomía de una fila de las células bajo del principio escrito. Hay necesidad de demostrar, que el paso o la modulación de una tonalidad a la otra puede hacerse nada más con tres modos y con principio de economía musical. Todos los modos superiores son modos enarmónicos. Modulación es un proceso de cambio y su determinación en el camino corto de una tonalidad a la otra. Ejemplo: de C-dur a H-dur (Figure 3). Su distancia es $1 / 2$ tono en escala diatónica. Este proceso confirma la idea sobre la disposición sucesiva de las CCI en MB. La modulación se efectúa bajo el principio de la economía de los recursos musicales (acordes).

1. Demonstration of the modulation in three degrees of the kinship of the tonalities

The book "Treatise on Harmony" (Fokin S. K., 2017) was developed with a vision of the anatomy of the cochlea, where hypothetically the places of the Internal Ciliated Ciliates that occur in the anatomy of a row of cells under the written principle are associated. There is a need to demonstrate that the passage or modulation from one key to the other can be done only with three modes and with the principle of musical economy. All the upper modes are enharmonic modes. Modulation is a process of change and its determination in the short path from one shade to the other. Example: from $\mathrm{C}$-dur to $\mathrm{H}-$ dur (Figure 3).
Its distance is $1 / 2$ tone in diatonic scale. This process confirms the idea about the successive arrangement of CCIs in MB. Modulation is carried out under the principle of the economy of musical resources (chords).

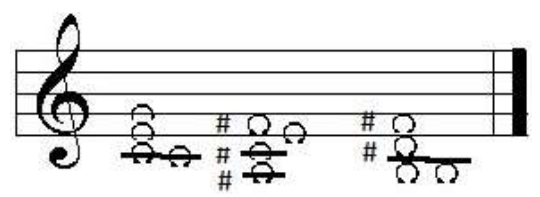

Figure 3 Modulatión from C-dur to H-dur

b) Organización silábica de la palabra

1. Syllabic organization of the word

According to Fokin (Fokin S.K., 2016), the acquisition of speech by the child can always lead, and nothing more always, when there is the syllable CV (consonant + vowel), which is universally acceptable for all the languages of the world (Trubetzkoy, 1939). Otherwise, the syllables multiply, and the child's speech development is complicated. The acquisition, construction and training of reading skills will also be hindered. In the Dictionary of the Spanish language (Royal Spanish Academy, 2001), you can find the BA syllable in syllabic groups: $\mathrm{CV}, \mathrm{CVC}$ and CVV. Since then, the BA syllable (CV) in its CVC grammar construction, CVV increases self-knowledge by $1500 \%$ in speech acquisition. It's hard to disagree that children of the early age don't break down the syllable into isolated sounds. The following constructions are testimonies to the unnecessary and complex multiplication of syllabic organization.

\begin{tabular}{|c|c|c|c|c|}
\hline$\overline{c V}$ & \multicolumn{2}{|c|}{ cuc } & cVV & CV/CVC+CVV \\
\hline \multirow[t]{6}{*}{ BA } & $\begin{array}{c}\text { Bac } \\
\text { bacteria }\end{array}$ & $\begin{array}{c}\text { BAM } \\
\text { bambú }\end{array}$ & $\begin{array}{c}\text { Baf } \\
\text { betenero }\end{array}$ & $\begin{array}{l}\text { BA/ SE AUMENTO } \\
\text { EL } \\
\text { CONOCIMIENTO }\end{array}$ \\
\hline & $\begin{array}{c}\text { BAO } \\
\text { badiminton }\end{array}$ & $\begin{array}{l}\text { BaN } \\
\text { banco }\end{array}$ & $\begin{array}{c}\text { Bail } \\
\text { baile }\end{array}$ & EM $1500 \%$ \\
\hline & $\begin{array}{l}\text { Baf } \\
\text { bafle }\end{array}$ & $\begin{array}{c}\text { BAP } \\
\text { baptista }\end{array}$ & $\begin{array}{c}\text { BAO } \\
\text { baobab }\end{array}$ & \\
\hline & $\begin{array}{l}\text { MAG } \\
\text { bagre }\end{array}$ & $\begin{array}{l}\text { BAR } \\
\text { barba }\end{array}$ & $\begin{array}{l}\text { Bau } \\
\text { baúl }\end{array}$ & \\
\hline & $\begin{array}{c}\text { BAL } \\
\text { balbuceo }\end{array}$ & $\begin{array}{l}\text { gAs } \\
\text { bastón }\end{array}$ & & \\
\hline & $\begin{array}{l}\text { BALL } \\
\text { Ballesta }\end{array}$ & & & \\
\hline 0. & & & & \\
\hline
\end{tabular}

Figure 4 The phono-morpho-syllabic organization

Es importante comprender, que el nacimiento de las primeras palabras en el niño empieza no por los sonidos del balbuceo, pero por la apropiación de los sonidos del habla de adultos, escuchados por niño.

FOKIN, Sergei Konstantinovich \& ARICEAGA-PAREDES, Rafael. Evolutionary Method for Learning to ReadJournal Civil Engineering. 2021 
It is important to understand that the birth of the first words in the child begins not by the sounds of babbling, but by the appropriation of the speech sounds of adults, heard by the child.

It's hard to disagree that children of the early age don't break down the syllable into isolated sounds. For example, answering the question how many sounds in the word mom, they say that there are two: ma and ther (Zinder, 2007). As a complement to the traditional and official to determine a stage of pre-reading in the development of man, the definition of the structural unity of the word will be given. A syllable is a combination or presentation of one or two sounds. According to Luria, (Luria A. R., 1974) the successive acquisition of speech is accompanied by a phonetic and morfemic increase: "The world doubles." In other words, the period of acquisition, construction and formation of speech has temporarily short stages.

Thus, from a point of view and putting as a principle of biological, acoustic, musical, and linguistic economy, the following structural groups-graphs can be proposed with the phonomorpho-syllabic organization:

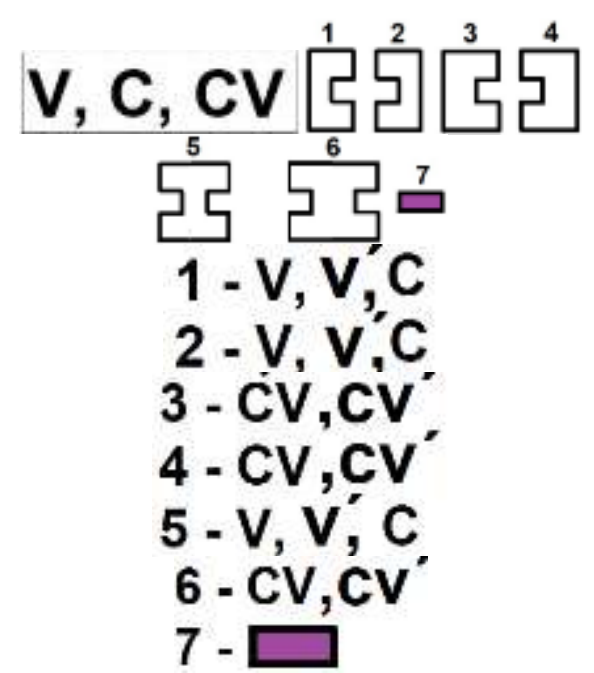

Figure 5

\section{Colores}

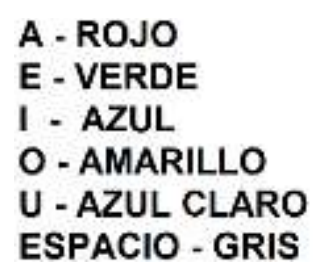

Figure 6
Examples:

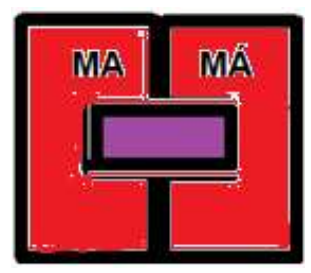

Figure 7

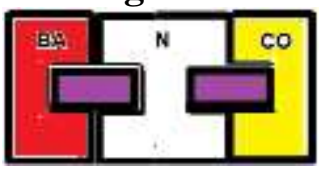

Figure 8

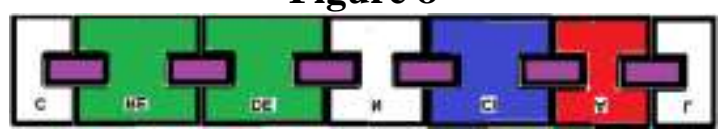

Figure 9

\section{Methodology}

In the development and implementation of the evolutionary method to learn to read, the principles of biological, musical, acoustic, linguistic and human development economics are used. The universe of the "Learning to Read" method is a technological educational means of pedagogical use; it is a spiral organization with circular motion. In other words, the learning of reading is carried out through corrections of the development of the sensory and cognitive systems of the school classroom subjects. It is organized by two modules:

1. "Intelligentsystem in sensory and cognitive development for the prereading stage" (Fokin S. K., Ariceaga Paredes R. Perez Perez T. 2021)

2. Software to learn to read

\section{Software Evolutionary method "Learning to read"}

The software is programmed in Laravel Framework.

Database. Program is organized as follows: Blocks of:

1. syllables $\mathrm{CV}, \mathrm{CV}^{\prime}, \mathrm{V}, \mathrm{V}^{\prime}$ and $\mathrm{C}$

2. punctuation 
The syllables are presented based on sounds of a musical system of the tempered organization (lat. temperatio: fair proportion). Consonants $(\mathrm{C})$ are presented with noise and in height graduation: high, medium, and low.

The variables of sound syllables are tone height $261.76 \mathrm{~Hz}-698.60 \mathrm{~Hz}$ (Recuero López, 2000) and duration $25 \mathrm{~ms}-55 \mathrm{~ms}$ (variant 1). Time of $15 \mathrm{~ms}-45 \mathrm{~ms}$ (variant 2).

The screens have work fields of:

1. Teacher

2. Pupil

3. Words, phrases, and text, e.g., stories with illustrations

4. Statistics (error, correction and development)

Functions of the teacher in the process of tuning to achieve an understanding and understanding of the meanings of words, phrases, and text:

1. Program on the teacher's screen the thematic algorithms through morphophono-syllable in different variables: height of the tone, its volume and duration time

2. Record, if necessary, the instructions

3. Save the work material for the student

4. Analyze the results of student work

5. Recommend, if necessary, the repetition of the auditory development cycle

6. Prepare thematic sequence of content, following a principle of the simple to the complex

Student functions:

1. Enter your screen

2. Follow the instructions

3. "Write" words, phrases, or text

4. Finish the job

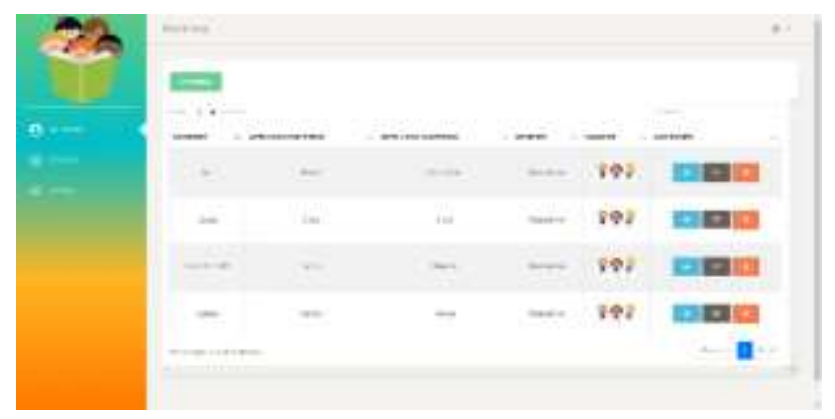

Figure 10 Windows Teacher Student Screen

ISSN-2523-2452

ECORFAN ${ }^{\circledR}$ All rights reserved

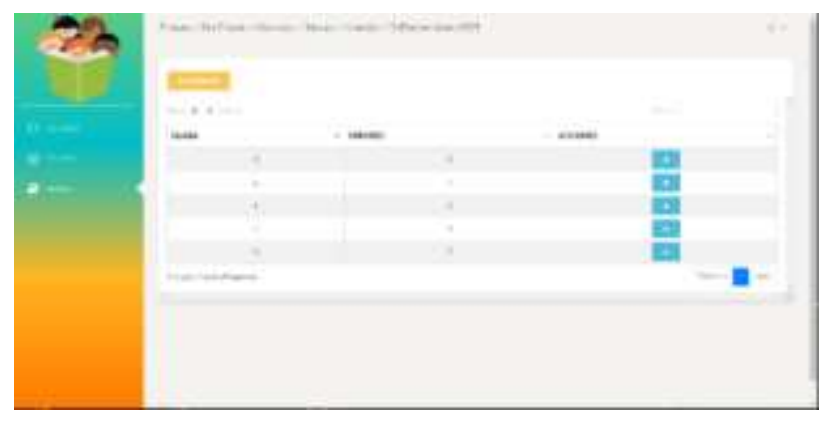

Figure 11 Windows Teacher Screen of Attempts

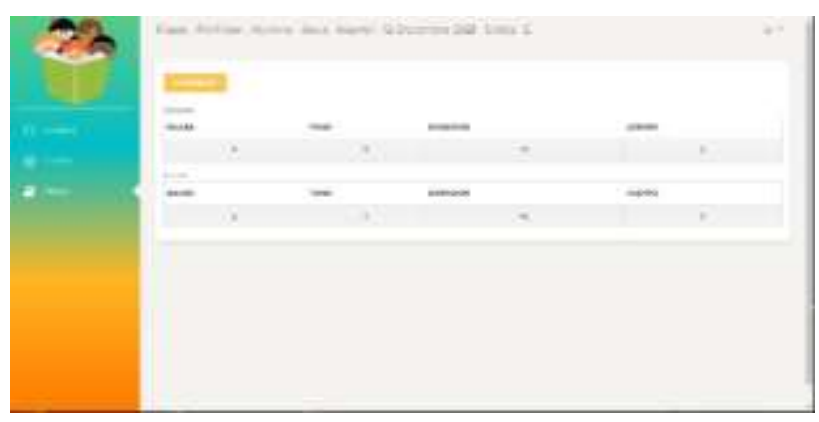

Figure 12 Windows Teacher Error Screen

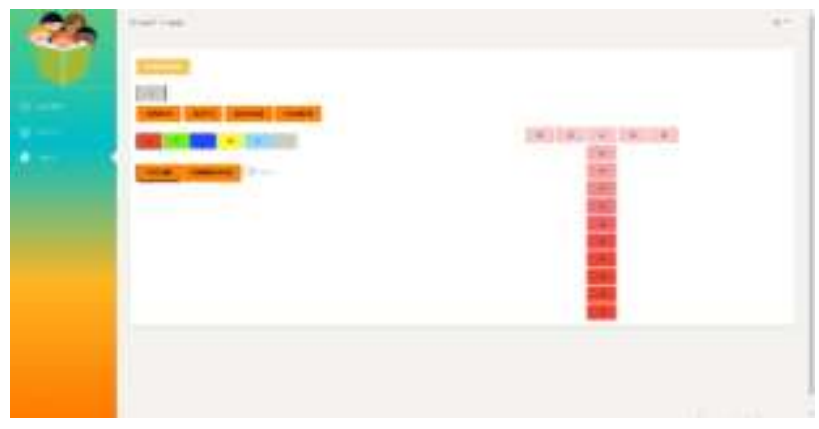

Figure 13 Windows Teacher Word Screen, Phrases

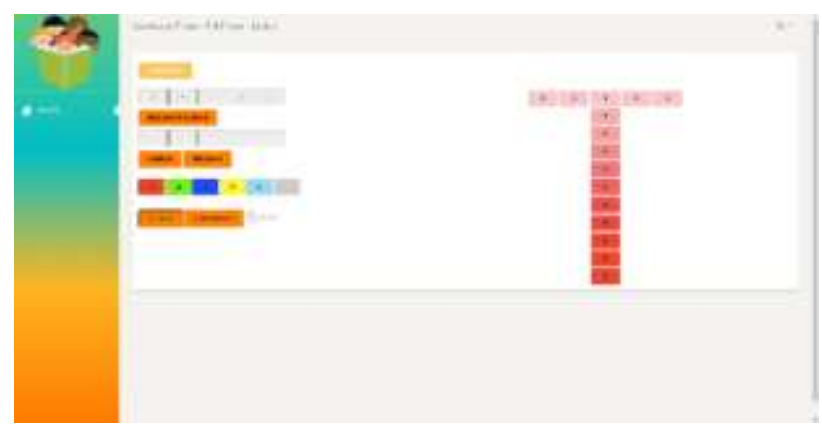

Figure 14 Windows Student Answering Words, Phrases Screen

\section{Conclusions}

The pedagogical need contributed to developing the method so that the child of early age can learn to read in a short time, acquiring, building, and forming the necessary knowledge. The technological support made it possible to establish the tuned communication in the school classroom between teacher and student and, at the same time, to objectify the process of teaching and learning didactics. 
The man-reader is prepared to open and read the Book of Life, paying attention to knowing the world around us.

\section{References}

Anojin, P. K. (1998). Cybernetics of functional systems: Selected works. Moscú: Medicine.

Ariceaga Paredes R., F. S. (2012). Proceedings XXXI World Congress of Audiology. Some Considerations about Natural Laws and Principles in Cochlear Mechanics (pág. 139). Moscow: ISA.

Békésy, G. v. (1960). Experiments in Hearing. McGraw-Hill Book Company, Inc.

Campuzano Reyna, N. F. (2005). Los Métodos de Lectura y Escritura en México (Siglos XVI al XX). Toluca: Escuela Normal No. 3 de Toluca.

Cohen, J. (1973). Sensación y percepción auditiva y de los sentidos menores. México: Trillas.

Courtenay, J. B. (1963). Izbrannye trudy po obshemu yazykoznaniu. Moscú: Academia de la ciencia. URSS.

Fant, G. (2012). Acoustic Theory of speech production. Walter de Greuter.

Flanagan, J. (1968). Análisis, sintesis y la percepción del habla. Moscú.

Fokin S., K. (2008). Aprendiendo a leer. Toluca. México: No publicado.

Fokin S.K., C. D. (2016). Orientación fonológica sobre la organización silábicaen la Licenciatura de la Educación Preescolar. En M. E. Murueta, Aprendizaje creador y nuevas prácticas pedagógicas (págs. 164-189). México: Amapsi Editorial, ISBN: 978-6077506-29-4.

Fokin, S. A. (2018). Discovering the Path to Comprehension of the Cochlea Mechanics. México: SEP-INDAUTOR 03-2018012410294900-01, no publicado.

Fokin, S. K. (2017). Tratado de Armonía. México: SEP-INDAUTOR, Registro: 03-2017 11210592800-01, no publicado.
Helmholtz, H. v. (1913). Die Lehre von den Tonempfindungen als Physiologische Grundlage fur die Theorie der Musik. Braunschweig: Verlag von Friedr. Vieweg und Sohn.

Luria, A. R. (1974). Cerebro y lenguaje. Barcelona: Fontanella.

Luria, A. R. (1984). Conciencia y lenguaje. Madrid: Visor Libros.

Martinet, A. (1955). Economie des changements fonetiques. Berne.

Popper, K. (1994). Knowledge and the Bodymind Problem: In Defence of Interaction. Psychology Press.

Real Academia Española. (2001). Diccionario de la lengua española. Madrid: Espasa Calpe, S. A.

Saussure, F. d. (1968-1974). Cours de linguistique générale, édition critique par Rudolf Engler, 2 vol. Wiesbaden: Harrassowitz.

Schmidt, R. (1981). Fundamentals of Sensory Physiology. Berlin: Springer-Verlag.

Trubetzkoy, N. (1939). Grundzüge der Phonologie. Prague: Travaux du Cercle Linguistique de Prague, 7.

Vigotsky, L. (1995). Pensamiento y lenguaje. Paidos Iberica Ediciones S A.

Zinder, L. R. (2007). Obshaia fonetica. SanPeterburgo: Academia. 